\title{
RHO wt Allele
}

National Cancer Institute

\section{Source}

National Cancer Institute. RHO wt Allele. NCI Thesaurus. Code C129079.

Human RHO wild-type allele is located in the vicinity of $3 q 22.1$ and is approximately $7 \mathrm{~kb}$ in length. This allele, which encodes rhodopsin protein, is involved in photoreceptor cell activity and maintenance. Mutation of the gene is associated with congenital stationary night blindness, retinitis pigmentosa 4, and retinitis punctata albescens. 